\title{
Traditional Preparations and Methanol Extracts of Medicinal Plants from Papua New Guinea Exhibit Similar Cytochrome P450 Inhibition
}

\author{
Erica C. Larson, ${ }^{1}$ Christopher D. Pond, ${ }^{1}$ Prem P. Rai, ${ }^{2}$ Teatulohi K. Matainaho, ${ }^{2,3}$ \\ Pius Piskaut, ${ }^{3}$ Michael R. Franklin, ${ }^{1}$ and Louis R. Barrows ${ }^{1,2,3}$ \\ ${ }^{1}$ Department of Pharmacology and Toxicology, University of Utah, 30 S. 2000 E., Salt Lake City, UT 84112, USA \\ ${ }^{2}$ School of Medicine and Health Sciences, University of Papua New Guinea, P.O. Box 5623, Boroko, NCD, Papua New Guinea \\ ${ }^{3}$ School of Natural and Physical Sciences, University of Papua New Guinea, P.O. Box 5623, Boroko, NCD, Papua New Guinea \\ Correspondence should be addressed to Louis R. Barrows; lbarrows@pharm.utah.edu
}

Received 25 April 2016; Accepted 21 July 2016

Academic Editor: Dolores García Giménez

Copyright (C) 2016 Erica C. Larson et al. This is an open access article distributed under the Creative Commons Attribution License, which permits unrestricted use, distribution, and reproduction in any medium, provided the original work is properly cited.

\begin{abstract}
The hypothesis underlying this current work is that fresh juice expressed from Papua New Guinea (PNG) medicinal plants (succus) will inhibit human Cytochrome P450s (CYPs). The CYP inhibitory activity identified in fresh material was compared with inhibition in methanol extracts of dried material. Succus is the most common method of traditional medicine (TM) preparation for consumption in PNG. There is increasing concern that TMs might antagonize or complicate drug therapy. We have previously shown that methanol extracts of commonly consumed PNG medicinal plants are able to induce and/or inhibit human CYPs in vitro. In this current work plant succus was prepared from fresh plant leaves. Inhibition of three major CYPs was determined using human liver microsomes and enzyme-selective model substrates. Of 15 species tested, succus from 6/15 was found to inhibit CYP1A2, 7/15 inhibited CYP3A4, and 4/15 inhibited CYP2D6. Chi-squared tests determined differences in inhibitory activity between succus and methanol preparations. Over $80 \%$ agreement was found. Thus, fresh juice from PNG medicinal plants does exhibit the potential to complicate drug therapy in at risk populations. Further, the general reproducibility of these findings suggests that methanol extraction of dried material is a reasonable surrogate preparation method for fresh plant samples.
\end{abstract}

\section{Introduction}

In Papua New Guinea (PNG) approximately $0.6 \%$ of the 7 million population is living with human immunodeficiency virus (HIV) [1] while over 30\% [2] is infected with tuberculosis (TB). HIV is often a comorbidity of tuberculosis [2]. Standard treatment of HIV and TB requires long-term administration of antiretroviral (ARV) or anti-TB drugs. In PNG, traditional medicine (TM, bus marasin) is widely practiced [3], as is the use of Western medicines. In fact, in PNG it is thought that $50 \%$ of the population relies solely on traditional medicines, with no access to Western medicines [4]. Factors that influence use of traditional medicine for health promotion include cost of Western medicines, limited access to distribution centers, and poorly stocked aid posts and healthcare facilities in rural areas [5].
ARV and anti-TB therapies are often complicated by drug-drug interactions [6], most commonly via effects on drug metabolism performed by Cytochrome P450 enzymes (CYPs) present in the liver. CYPs are a superfamily of enzymes that metabolize drugs to a more-readily excreted form. Drugs interact with CYPs through two major mechanisms: enzyme inhibition and enhanced enzyme expression, termed induction [6]. In an effort to determine potential impact of traditional medicines on HIV/TB treatment efficacy, we previously assessed methanol extracts from 69 of the 100 most commonly used medicinal plants (as listed in UPNG Traditional Medicines Database [7, 8]), collected from 7 PNG provinces, for human CYP induction and inhibition in vitro [9]. Close to two-thirds of the medicinal plant extracts exhibited potent CYP inhibition, while almost onethird of them significantly induced CYP expression. This 
work confirmed that many PNG medicinal plants have the potential to induce or inhibit CYPs and may possibly interfere with the therapeutic efficacy of ARV and anti-TB drugs.

In PNG the most common method of medical plant preparation for consumption is to express the juice, often using a little water to facilitate capture [10]. Recent literature has compared fresh plant juice to alcohol extracts for antibiotic or antioxidant activity often demonstrating quantitative variation in the components isolated [11-18]. Such a comparison has not been made concerning drug metabolism, however, and the relevance of CYP inhibition by methanol extracts of medical plants to actual bus marasin practice has been questioned. It is important to resolve this question in PNG in order for the PNG National Aids Council to institute counselling of patients that receive ARV or TB therapy regarding the use of TMs. Data is presented here that shows that succus from several PNG medicinal plants can indeed inhibit human CYPs with 6 of 15 species inhibiting CYP1A2, 7/15 inhibiting CYP3A4, and 4/15 inhibiting CYP2D6. In addition, the data reveal that CYP inhibition observed in methanol extracts of dried plant material was by and large recapitulated in the succus preparations, with no statistically significant difference $(p<0.05)$ observed in their abilities to inhibit CYPs in vitro. Elements of this work were presented at the American Society of Pharmacognosy 2015 annual meeting [19].

\section{Materials and Methods}

2.1. Medicinal Plant Collection. A team from the University of Papua New Guinea (UPNG) consisting of trained botanists, pharmacognosists, and students interviewed traditional healers in the rural communities of Drekikir in the East Sepik Province, Dogura in the Milne Bay Province, Arawa and Namatoa in Bougainville, and National Capitol District. Fresh medicinal plant materials indicated in the traditional healer interview were collected, and expressed juices were prepared and refrigerated until return to the BioDiscovery laboratory at UPNG School of Medicine and Health Sciences, Port Moresby, for rotary evaporation. In accordance with our established protocols which require informed consent prior to interviews [8], plant information, including local names and medicinal uses, was documented. Voucher samples were prepared for plant identification by UPNG Biological Sciences Herbarium staff where vouchers are stored.

2.2. Medicinal Plant Extraction. Plant succus prepared from $\sim 200 \mathrm{~g}$ fresh plant leaves was evaporated to dryness and dissolved in $100 \mathrm{~mL}$ of $100 \%$ methanol $(\mathrm{MeOH})$ overnight. Extracts $(50 \mathrm{~mL})$ were then transferred to clean vessels, evaporated to dryness, and redissolved in dimethyl sulfoxide (DMSO) to yield a final concentration of approximately $10 \mathrm{mg} / \mathrm{mL}$.

2.3. CYP Inhibition Assays. Inhibition assays were performed as previously described [9]. In brief, plant extracts were added to human liver microsomes enriched in their respective CYP subtype (Celsis). Substrate was added at half-saturating
$\left(K_{m}\right)$ or saturating $\left(V_{\max }\right)$ concentrations. Substrates selective for their respective CYPs are as follows: methoxyresorufin (MR), CYP1A2; 7-benzyloxyquinoline (7-BQ), CYP3A4; and 7-methoxy-4-(aminomethyl)-coumarin (MAMC), CYP2D6. $\mathrm{NADPH}$ was added in excess $(60 \mathrm{mM})$ and the formation of fluorescent product was measured using a Biotek-Synergy 2 Microplate Reader [20]. Extracts showing $>50 \%$ inhibition at $K_{m}$ and/or $V_{\max }$ concentrations were deemed inhibitory (moderate to strong inhibitors as defined by FDA, 2012 [21]).

2.4. Statistics. To investigate statistical significance between TM preparation methods, data from the previous methanol study and current succus study was organized into a $2 \times 2$ contingency table and Chi-squared tests performed for each CYP subtype. Results were considered statistically significant when $p<0.05$. Pairwise comparisons between of medicinal plants of like genus and species from the methanol study and current succus study were used to calculate percent agreement.

\section{Results}

3.1. CYP Inhibition by Medicinal Plant Succus. Succus was prepared in the field from 17 species of medicinal plants that were previously analysed for inhibition of CYPs [9]. Some of the plants were collected in more than one location. Overall, $\sim 80 \%$ of CYP inhibitory activity found in the succus study was in agreement with the methanol study. CYP inhibition across the two studies organized by plant genus and species is summarized in Table 1. Juice from Calophyllum inophyllum L., Cassia alata L., Casuarina equisetifolia L., Passiflora foetida L., Morinda citrifolia L. (one of 2 collections), and Terminalia catappa L. was found to inhibit CYP 1A2. Plant succi that inhibited CYP 3A4 were Calophyllum inophyllum L., Cassia alata L., Casuarina equisetifolia L., Ipomea pes-caprae L., Morinda citrifolia L., Passiflora foetida L., Sida rhombifolia L., and Terminalia catappa L. For CYP 1A2 inhibition, only Calophyllum inophyllum L., Cassia alata L., Passiflora foetida L., and Terminalia catappa L. were active.

3.2. CYP Inhibition: Plant Succus Compared to Methanol Extracts. Overall, CYP inhibitory activity (or lack thereof) determined for the succus plant preparations agreed with the previously determined inhibitory activity determined for the methanol preparations. For CYP1A2, out of 20 pairwise comparisons, nonagreement was found for 5: Ipomea pescaprae L., Morinda citrifolia L. (one of two preparations), Passiflora foetida L., Premna obtusifolia R.Br., Sida rhombifolia L., and Terminalia catappa L. For CYP3A4, out of 20 pairwise comparisons, nonagreement was found for 3: Cassia alata L. (two of two preparations) and Sida rhombifolia L. For CYP2D6, out of 20 pairwise comparisons, nonagreement was found for 4: Bidens pilosa L. (one of two preparations), Casuarina equisetifolia L., and Passiflora foetida L. (two of two preparations). Furthermore, several of the nonagreements were likely due to the magnitude of inhibition being close to the adopted "significant" cutoff of $50 \%$ for moderately 
TABLE 1: CYP inhibition across methanol (M) and succus (S) studies.

\begin{tabular}{|c|c|c|c|c|c|c|c|c|c|c|}
\hline \multirow{2}{*}{ Genus and species } & \multirow{2}{*}{$\mathrm{M} / \mathrm{S}$} & \multicolumn{2}{|c|}{$\begin{array}{c}\text { CYP1A2 } \\
\% \text { inhibition }\end{array}$} & \multirow{2}{*}{$\begin{array}{c}\text { Inh? } \\
(\mathrm{Y} / \mathrm{N})\end{array}$} & \multicolumn{2}{|c|}{$\begin{array}{c}\text { CYP3A4 } \\
\text { \% inhibition }\end{array}$} & \multirow{2}{*}{$\begin{array}{c}\text { Inh? } \\
(\mathrm{Y} / \mathrm{N})\end{array}$} & \multicolumn{2}{|c|}{$\begin{array}{c}\text { CYP2D6 } \\
\text { \% inhibition }\end{array}$} & \multirow{2}{*}{$\begin{array}{l}\text { Inh? } \\
(\mathrm{Y} / \mathrm{N})\end{array}$} \\
\hline & & $\begin{array}{c}\mathrm{MR} \\
(2.0 \mu \mathrm{M})\end{array}$ & $\begin{array}{c}\mathrm{MR} \\
(0.4 \mu \mathrm{M})\end{array}$ & & $\begin{array}{c}\text { 7-BQ } \\
(500 \mu \mathrm{M})\end{array}$ & $\begin{array}{c}\text { 7-BQ } \\
(100 \mu \mathrm{M})\end{array}$ & & $\begin{array}{l}\text { MAMC } \\
(100 \mu \mathrm{M})\end{array}$ & $\begin{array}{l}\text { MAMC } \\
(40 \mu \mathrm{M})\end{array}$ & \\
\hline Bidens pilosa (Asteraceae) & M & - & - & $\mathrm{N}^{\#}$ & - & - & $\mathrm{N}^{\#}$ & - & - & $\mathrm{N}^{\#}$ \\
\hline Bidens pilosa (Asteraceae) & M & - & - & $\mathrm{N}^{\#}$ & - & - & $\mathrm{N}^{\#}$ & - & 51 & $\mathrm{Y}^{\dagger}$ \\
\hline Bidens pilosa (Asteraceae) & S & - & - & $\mathrm{N}^{\# \#}$ & - & - & $\mathrm{N}^{\# \#}$ & - & - & $\mathrm{N}^{\# \#}$ \\
\hline $\begin{array}{l}\text { Calophyllum inophyllum } \\
\text { (Calophyllaceae) }\end{array}$ & M & 74 & 86 & $\mathrm{Y}^{\dagger}$ & - & 79 & $\mathrm{Y}^{\dagger}$ & 52 & 60 & $\mathrm{Y}^{\dagger}$ \\
\hline $\begin{array}{l}\text { Calophyllum inophyllum } \\
\text { (Calophyllaceae) }\end{array}$ & $S$ & 61 & 86 & $\mathrm{Y}^{\ddagger}$ & - & 79 & $\mathrm{Y}^{\ddagger}$ & 70 & - & $\mathrm{Y}^{\ddagger}$ \\
\hline Cassia alata (Fabaceae) & M & - & 54 & $\mathrm{Y}^{\dagger}$ & - & - & $\mathrm{N}^{\#}$ & 56 & 61 & $\mathrm{Y}^{\dagger}$ \\
\hline Cassia alata (Fabaceae) & M & 58 & 75 & $\mathrm{Y}^{\dagger}$ & - & 57 & $\mathrm{Y}^{\dagger}$ & 54 & - & $\mathrm{Y}^{\dagger}$ \\
\hline Cassia alata (Fabaceae) & $\mathrm{S}$ & - & 58 & $\mathrm{Y}^{\ddagger}$ & - & 62 & $\mathrm{Y}^{\ddagger}$ & 50 & 83 & $\mathrm{Y}^{\ddagger}$ \\
\hline $\begin{array}{l}\text { Casuarina equisetifolia } \\
\text { (Casuarinaceae) }\end{array}$ & M & 66 & 65 & $\mathrm{Y}^{\dagger}$ & 54 & 61 & $\mathrm{Y}^{\dagger}$ & - & 54 & $\mathrm{Y}^{\dagger}$ \\
\hline $\begin{array}{l}\text { Casuarina equisetifolia } \\
\text { (Casuarinaceae) }\end{array}$ & S & 70 & 80 & $\mathrm{Y}^{\ddagger}$ & - & 74 & $\mathrm{Y}^{\ddagger}$ & - & - & $\mathrm{N}^{\# \#}$ \\
\hline Eleusine indica (Poaceae) & M & - & - & $\mathrm{N}^{\#}$ & - & - & $\mathrm{N}^{\#}$ & - & - & $\mathrm{N}^{\#}$ \\
\hline Eleusine indica (Poaceae) & M & - & - & $\mathrm{N}^{\#}$ & - & - & $\mathrm{N}^{\#}$ & - & - & $\mathrm{N}^{\#}$ \\
\hline Eleusine indica (Poaceae) & $\mathrm{S}$ & - & - & $\mathrm{N}^{\# \#}$ & - & - & $\mathrm{N}^{\# \#}$ & - & - & $\mathrm{N}^{\# \#}$ \\
\hline Ficus wassa (Moraceae) & $\mathrm{M}$ & - & - & $\mathrm{N}^{\#}$ & - & - & $\mathrm{N}^{\#}$ & - & - & $\mathrm{N}^{\#}$ \\
\hline Ficus wassa (Moraceae) & S & - & - & $\mathrm{N}^{\# \#}$ & - & - & $\mathrm{N}^{\# \#}$ & - & - & $\mathrm{N}^{\# \#}$ \\
\hline $\begin{array}{l}\text { Hibiscus rosa-sinensis } \\
\text { (Malvaceae) }\end{array}$ & M & - & - & $\mathrm{N}^{\#}$ & - & - & $\mathrm{N}^{\#}$ & - & - & $\mathrm{N}^{\#}$ \\
\hline $\begin{array}{l}\text { Hibiscus rosa-sinensis } \\
\text { (Malvaceae) }\end{array}$ & S & - & - & $\mathrm{N}^{\# \#}$ & - & - & $\mathrm{N}^{\# \#}$ & - & - & $\mathrm{N}^{\# \#}$ \\
\hline $\begin{array}{l}\text { Hibiscus tiliaceus } \\
\text { (Malvaceae) }\end{array}$ & M & - & - & $\mathrm{N}^{\#}$ & - & - & $\mathrm{N}^{\#}$ & - & - & $\mathrm{N}^{\#}$ \\
\hline $\begin{array}{l}\text { Hibiscus tiliaceus } \\
\text { (Malvaceae) }\end{array}$ & S & - & - & $\mathrm{N}^{\# \#}$ & - & - & $\mathrm{N}^{\# \#}$ & - & - & $\mathrm{N}^{\# \#}$ \\
\hline $\begin{array}{l}\text { Ipomoea pes-caprae } \\
\text { (Convolvulaceae) }\end{array}$ & M & 56 & 69 & $\mathrm{Y}^{\dagger}$ & 58 & 60 & $\mathrm{Y}^{\dagger}$ & - & - & $\mathrm{N}^{\#}$ \\
\hline $\begin{array}{l}\text { Ipomoea pes-caprae } \\
\text { (Convolvulaceae) }\end{array}$ & $\mathrm{S}$ & - & - & $\mathrm{N}^{\# \#}$ & - & 70 & $\mathrm{Y}^{\ddagger}$ & - & - & $\mathrm{N}^{\# \#}$ \\
\hline $\begin{array}{l}\text { Laportea decumana } \\
\text { (Urticaceae) }\end{array}$ & $\mathrm{M}$ & - & - & $\mathrm{N}^{\#}$ & - & - & $\mathrm{N}^{\#}$ & - & - & $\mathrm{N}^{\#}$ \\
\hline $\begin{array}{l}\text { Laportea decumana } \\
\text { (Urticaceae) }\end{array}$ & $S$ & - & - & $\mathrm{N}^{\# \#}$ & - & - & $\mathrm{N}^{\# \#}$ & - & - & $\mathrm{N}^{\# \#}$ \\
\hline $\begin{array}{l}\text { Morinda citrifolia } \\
\text { (Rubiaceae) }\end{array}$ & $\mathrm{M}$ & - & - & $\mathrm{N}^{\#}$ & - & - & $\mathrm{N}^{\#}$ & - & - & $\mathrm{N}^{\#}$ \\
\hline $\begin{array}{l}\text { Morinda citrifolia } \\
\text { (Rubiaceae) }\end{array}$ & $S$ & - & 56 & $\mathrm{Y}^{\ddagger}$ & - & - & $\mathrm{N}^{\# \#}$ & - & - & $\mathrm{N}^{\# \#}$ \\
\hline $\begin{array}{l}\text { Morinda citrifolia } \\
\text { (Rubiaceae) }\end{array}$ & $S$ & - & - & $\mathrm{N}^{\# \#}$ & - & - & $\mathrm{N}^{\# \#}$ & - & - & $\mathrm{N}^{\# \#}$ \\
\hline $\begin{array}{l}\text { Passiflora foetida } \\
\text { (Passifloraceae) }\end{array}$ & $\mathrm{M}$ & - & - & $\mathrm{N}^{\#}$ & - & 51 & $\mathrm{Y}^{\dagger}$ & - & - & $\mathrm{N}^{\#}$ \\
\hline $\begin{array}{l}\text { Passiflora foetida } \\
\text { (Passifloraceae) }\end{array}$ & $\mathrm{S}$ & - & 52 & $\mathrm{Y}^{\ddagger}$ & - & 59 & $\mathrm{Y}^{\ddagger}$ & - & 52 & $\mathrm{Y}^{\ddagger}$ \\
\hline $\begin{array}{l}\text { Passiflora foetida } \\
\text { (Passifloraceae) }\end{array}$ & $S$ & - & 64 & $\mathrm{Y}^{\ddagger}$ & - & 69 & $\mathrm{Y}^{\ddagger}$ & 55 & 62 & $\mathrm{Y}^{\ddagger}$ \\
\hline
\end{tabular}


TABle 1: Continued.

\begin{tabular}{|c|c|c|c|c|c|c|c|c|c|c|}
\hline \multirow[b]{2}{*}{ Genus and species } & \multirow[b]{2}{*}{$\mathrm{M} / \mathrm{S}$} & \multicolumn{2}{|c|}{$\begin{array}{c}\text { CYP1A2 } \\
\text { \% inhibition }\end{array}$} & \multirow{2}{*}{$\begin{array}{l}\text { Inh? } \\
(\mathrm{Y} / \mathrm{N})\end{array}$} & \multicolumn{2}{|c|}{$\begin{array}{c}\text { CYP3A4 } \\
\% \text { inhibition }\end{array}$} & \multirow{2}{*}{$\begin{array}{l}\text { Inh? } \\
(\mathrm{Y} / \mathrm{N})\end{array}$} & \multicolumn{2}{|c|}{$\begin{array}{l}\text { CYP2D6 } \\
\text { \% inhibition }\end{array}$} & \multirow{2}{*}{$\begin{array}{l}\text { Inh? } \\
(\mathrm{Y} / \mathrm{N})\end{array}$} \\
\hline & & $\begin{array}{c}\mathrm{MR} \\
(2.0 \mu \mathrm{M})\end{array}$ & $\begin{array}{c}\mathrm{MR} \\
(0.4 \mu \mathrm{M})\end{array}$ & & $\begin{array}{c}\text { 7-BQ } \\
(500 \mu \mathrm{M}) \\
\end{array}$ & $\begin{array}{c}\text { 7-BQ } \\
(100 \mu \mathrm{M})\end{array}$ & & $\begin{array}{c}\text { MAMC } \\
(100 \mu \mathrm{M})\end{array}$ & $\begin{array}{l}\text { MAMC } \\
(40 \mu \mathrm{M})\end{array}$ & \\
\hline $\begin{array}{l}\text { Premna obtusifolia } \\
\text { (Verbenaceae) }\end{array}$ & $\mathrm{M}$ & 53 & 68 & $\mathrm{Y}^{\dagger}$ & - & - & $\mathrm{N}^{\#}$ & - & - & $\mathrm{N}^{\#}$ \\
\hline $\begin{array}{l}\text { Premna obtusifolia } \\
\text { (Verbenaceae) }\end{array}$ & $S$ & - & - & $\mathrm{N}^{\# \#}$ & - & - & $\mathrm{N}^{\# \#}$ & - & - & $\mathrm{N}^{\# \#}$ \\
\hline $\begin{array}{l}\text { Sida rhombifolia } \\
\text { (Malvaceae) }\end{array}$ & $\mathrm{M}$ & 54 & 75 & $\mathrm{Y}^{\dagger}$ & - & - & $\mathrm{N}^{\#}$ & - & - & $\mathrm{N}^{\#}$ \\
\hline $\begin{array}{l}\text { Sida rhombifolia } \\
\text { (Malvaceae) }\end{array}$ & S & - & - & $\mathrm{N}^{\# \#}$ & - & 60 & $\mathrm{Y}^{\ddagger}$ & - & - & $\mathrm{N}^{\# \#}$ \\
\hline $\begin{array}{l}\text { Terminalia catappa } \\
\text { (Combretaceae) }\end{array}$ & M & 96 & 92 & $\mathrm{Y}^{\dagger}$ & 64 & 80 & $\mathrm{Y}^{\dagger}$ & 67 & 81 & $\mathrm{Y}^{\dagger}$ \\
\hline $\begin{array}{l}\text { Terminalia catappa } \\
\text { (Combretaceae) }\end{array}$ & S & 84 & 76 & $\mathrm{Y}^{\ddagger}$ & 73 & 87 & $\mathrm{Y}^{*}$ & 55 & 68 & $\mathrm{Y}^{\ddagger}$ \\
\hline
\end{tabular}

Inhibition indicated by “ $\dagger$ ” (for M study) and“ $\ddagger ”$ (for $S$ study). No inhibition indicated by “\#” (for M study) and“\#\#” (for S study).

$(-)$ activity was $<50 \%$ inhibition.

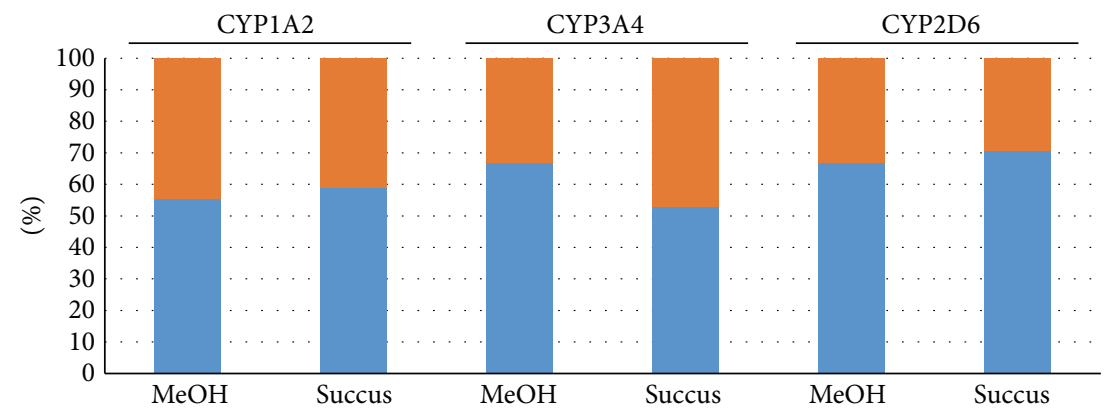

- Noninhibitory

- Inhibitory

\begin{tabular}{|c|c|c|c|c|c|c|c|}
\hline \multirow{3}{*}{ CYP subtype } & \multirow{3}{*}{$\begin{array}{l}\text { TM preparation } \\
\text { method }\end{array}$} & \multicolumn{4}{|c|}{ Inhibition } & \multirow{3}{*}{ Total } & \multirow{3}{*}{$p$ value } \\
\hline & & \multicolumn{2}{|c|}{ Yes } & \multicolumn{2}{|c|}{ No } & & \\
\hline & & $n$ & $\%$ & $n$ & $\%$ & & \\
\hline \multirow{2}{*}{ CYP1A2 } & $\mathrm{MeOH}$ & 8 & 44.4 & 10 & 55.6 & 18 & \multirow{2}{*}{0.8452} \\
\hline & Succus & 7 & 41.2 & 10 & 58.8 & 17 & \\
\hline \multirow{2}{*}{ CYP3A4 } & $\mathrm{MeOH}$ & 6 & 33.3 & 12 & 66.7 & 18 & \multirow{2}{*}{0.4074} \\
\hline & Succus & 8 & 47.1 & 9 & 52.9 & 17 & \\
\hline \multirow{2}{*}{ CYP2D6 } & $\mathrm{MeOH}$ & 6 & 33.3 & 12 & 66.7 & 18 & \multirow{2}{*}{0.8028} \\
\hline & Succus & 5 & 29.4 & 12 & 70.6 & 17 & \\
\hline
\end{tabular}

Significance level is $p<0.05$.

FIGURE 1: Comparison of CYP inhibitory activity based on TM preparation method.

active inhibitors [21]. Examples would be 2D6 inhibition of Bidens pilosa L. (51\% inhibition at $40 \mu \mathrm{M}$ substrate), one of the two Morinda citrifolia L. samples (56\% inhibition at $40 \mu \mathrm{M}$ substrate), and so forth. In any case, there was no statistical difference for CYP inhibition found in the succus study compared to the methanol study for CYP1A2, 3A4, or 2D6 (Figure 1; $p<0.05$ ), overall agreement being approximately $84 \%$. Therefore, methanol preparations may serve as a surrogate for traditional preparation methods, when fresh plant material is difficult to obtain.

\section{Discussion}

In PNG the most common method of medicinal plant preparation for oral consumption is squeezing of juice from the fresh plant (succus). In contrast, our previous work 
measured CYP inhibition by methanol extracts of dried medicinal plant parts. Therefore, this work investigated CYP inhibition by succus, the more traditional method preparation.

Antiretroviral and anti-TB therapies employ combinations of drugs to reduce disease burden. Metabolism of the majority of these drugs is performed by CYP3A4. Protease inhibitors (PIs) are the most common ARV component associated with drug-drug interactions. PIs inhibit CYP metabolism, a phenomenon which is often utilized to enhance pharmacokinetic profiles of other PIs taken concomitantly [22-24]. Common anti-TB drugs, such as isoniazid and rifapentine, have also been shown to cause CYP inhibition in vitro [25]. Excessive CYP inhibition can have negative consequences due to elevated concentrations of ARV or anti-TB drugs in the body $[26,27]$.

Traditional medicines have the potential to exacerbate adverse drug effects through plant-drug interactions. For instance, cat's claw, Uncaria tomentosa (Willd.), an herbal medicine taken to boost the immune system, has been observed to elevate protease inhibitor levels in the blood through CYP3A4 inhibition [28, 29]. Identification of herb-drug interactions, especially in countries where herbal medicines are widely practiced, is vital in order to avoid development of toxicity in patients receiving Western medicines for HIV and/or TB. Traditional medicine is widely practiced in Papua New Guinea (PNG). It is a likely scenario that traditional medicines will be used in combination with ARV and anti-TB drugs throughout much of PNG. Previously, we showed that around $40 \%$ of the PNG medicinal plant methanol extracts tested inhibited CYP3A4 [9]. In addition, CYP1A2 and CYP2D6, which are involved to a lesser extent with respect to ARV and anti-TB drug metabolism, were shown to be inhibited by around $28 \%$ and $29 \%$ of the PNG medicinal plant extracts tested, respectively.

Many factors can contribute to the irreproducibility of plant extract activity when extracts from independently collected plants of the same species are compared. It is well accepted that the chemical composition of recollected plant extracts can vary with location of collection, season of collection, varieties or cultivars sampled, and even age of the plant parts collected [30-34]. The solvent used for plant extraction can also greatly influence the chemical composition of the extract [35]. Recent work comparing juice to alcohol extracts has tended to indicate superior antibiotic activity in fresh juice [11-16], whereas superior antioxidant activity tended to follow extraction of flavones and phenols in alcohol or other preparations $[17,18]$. In our previous work, which compared some plants that were independently recollected, the total percent agreement in CYP activity was reasonably good (91\% for CYP induction and $72 \%$ for CYP inhibition) (unpublished data) and gave confidence that the activities identified in the methanol extracts of randomly collected dried plant samples were largely reproducible.

The ability of fresh juice from PNG medicinal plants to inhibit any of three human CYP enzymes was tested here in 17 samples from 15 species. Significant inhibition was determined in 7 of the 1A2 analyses, 8 of the 3A4 analyses, and 5 of the 2D6 analyses. Within this relatively limited dataset, statistical analysis could find no significant difference in the CYP inhibitory activity between the two extraction methods. This implies that the compounds likely responsible for drug-drug interaction appear to be, on average, equally accessed by traditional preparation of fresh plant material and by methanol extraction of dried material. The data indicate that methanol extraction of dried plant material is probably a reasonable surrogate preparation method when fresh plant samples cannot be obtained for analysis.

\section{Competing Interests}

The authors declare that they have no competing interests.

\section{Acknowledgments}

The authors would like to thank the Drekikir, Dogura, Arawa, and Namatoa communities for their participation in the current studies. Funding for this project was provided by PNG National Aids Council Secretariat (JTA International Sponsor Award no. 10020310) and NIH Fogarty Int. Ctr. U01 (TW006671) and the Wheeler Foundation through Wells Fargo, UT.

\section{References}

[1] UNAIDS, UNAIDS Report on The Global AIDS Epidemic 2013, http://www.unaids.org/en/resources/campaigns/globalreport2013/globalreport/.

[2] WHO, Global Health Observatory (GHO) Data, Papua New Guinea: Country Profiles-TB Country Profile, 2013, http://www .who.int/gho/countries/png/country_profiles/en/.

[3] P. P. Rai and G. Maibani, "The role of traditional medicine practitioners in managing HIV and AIDS related sicknesses in two provinces of Papua New Guinea," Pacific Journal of Medical Science, vol. 10, no. 2, pp. 3-15, 2012.

[4] WHO, "Legal Status of Traditional Medicine and Complementary/Alternative Medicine: A Worldwide Review-Papua New Guinea," 2001, http://apps.who.int/medicinedocs/en/d/ Jh2943e/9.12.html.

[5] National Policy on Traditional Medicine, National Department of Health Waigani and NCD, PNG, Papua, New Guinea, 2007.

[6] R. C. Rathbun and M. D. Liedtke, "Antiretroviral drug interactions: overview of interactions involving new and investigational agents and the role of therapeutic drug monitoring for management," Pharmaceutics, vol. 3, no. 4, pp. 745-781, 2011.

[7] P. P. Rai, "Traditional medicine database and its potential role in primary health care in Papua New Guinea," Pacific Journal of Medical Sciences, (form. Medical Sciences Bulletin), vol. 2: pp. 20-22, 2004.

[8] P. P. Rai and S. Saulei, "Establishment of a database on indigenous traditional medicine in Papua New Guinea," in Traditional Medicine in Papua New Guinea: Policy and Practices, P. P. Rai, Ed., pp. 61-70, University of Papua New Guinea Printery, 2010.

[9] E. C. Larson, L. B. Hathaway, J. G. Lamb et al., "Interactions of Papua New Guinea medicinal plant extracts with antiretroviral therapy," Journal of Ethnopharmacology, vol. 155, no. 3, pp. 14331440, 2014

[10] P. P. Rai, T. Matainaho, S. Saulei, and U. Ambihaipahar, Medicinal Plants in Papua New Guinea. Parts I \& II. WHO (World 
Health Organization), WHO Western Pacific Region, Manila, Philippines, 2009.

[11] G. Betanzos-Cabrera, P. Y. Montes-Rubio, H. E. Fabela-Illescas, H. Belefant-Miller, and J. C. Cancino-Diaz, "Antibacterial activity of fresh pomegranate juice against clinical strains of Staphylococcus epidermidis," Food \& Nutrition Research, vol. 59, Article ID 27620, 2015.

[12] M. Hussain, U. Farooq, M. Rashid et al., "Antimicrobial activity of fresh latex, juice and extract of Euphorbia hirta and Euphorbia thymifolia - an in vitro comparative study," International Journal of Pharma Sciences, vol. 4, no. 3, pp. 546-553, 2014.

[13] J. Parekh, D. Jadeja, and S. Chanda, "Efficacy of aqueous and methanol extracts of some medicinal plants for potential antibacterial activity," Turkish Journal of Biology, vol. 29, pp. 203-210, 2005.

[14] R. S. Policegoudra, S. Saikia, J. Das, P. Chattopadhyay, L. Singh, and V. Veer, "Phenolic content, antioxidant activity, antibacterial activity and phytochemical composition of Garcinia lancifolia," Indian Journal of Pharmaceutical Sciences, vol. 74, no. 3, pp. 268-271, 2012.

[15] M. M. Rahman, M. M. I. Sheikh, S. A. Sharmin et al., "Antibacterial activity of leaf juice and extracts of Moringa oleifera Lam. against some human pathogenic bacteria," Chiang Mai University Journal of Natural Sciences, vol. 8, no. 2, pp. 219-227, 2009.

[16] R. K. Saha, N. M. Zaman, and P. Roy, "Comparative evaluation of the medicinal activities of methanolic extract of seeds, fruit pulps and fresh juice of Syzygium cumini in vitro," Journal of Coastal Life Medicine, vol. 1, no. 4, pp. 300-308, 2013.

[17] R. Jakmatakul, R. Suttisri, and P. Tengamnuay, "Evaluation of antityrosinase and antioxidant activities of Raphanus sativus root: comparison between freeze-dried juice and methanolic extract," Thai Journal of Pharmaceutical Sciences, vol. 33, no. 1, pp. 22-30, 2009.

[18] T. Sun, J. R. Powers, and J. Tang, "Evaluation of the antioxidant activity of asparagus, broccoli and their juices," Food Chemistry, vol. 105, no. 1, pp. 101-106, 2007.

[19] E. C. Larson, C. D. Pond, P. Rai et al., "Traditional preparations and methanolic extracts of plants from Papua New Guinea exhibit similar cytochrome P450 inhibition," Planta Medica, vol. 81, article PW12, 2015.

[20] J. G. Lamb, L. B. Hathaway, M. A. Munger, J. L. Raucy, and M. R. Franklin, "Nanosilver particle effects on drug metabolism in vitro," Drug Metabolism and Disposition, vol. 38, no. 12, pp. 2246-2251, 2010.

[21] FDA, Guidance for Industry; Drug Interaction Studies-Study Design, Data Analysis, Implications for Dosing, and Labeling Recommendations, US HHSCDER, Silver Spring, Md, USA, 2012.

[22] A. Hsu, G. R. Granneman, G. Cao et al., "Pharmacokinetic interaction between ritonavir and indinavir in healthy volunteers," Antimicrobial Agents and Chemotherapy, vol. 42, no. 11, pp. 2784-2791, 1998.

[23] J. R. King, H. Wynn, R. Brundage, and E. P. Acosta, "Pharmacokinetic enhancement of protease inhibitor therapy," Clinical Pharmacokinetics, vol. 43, no. 5, pp. 291-310, 2004.

[24] F. Josephson, "Drug-drug interactions in the treatment of HIV infection: focus on pharmacokinetic enhancement through CYP3A inhibition," Journal of Internal Medicine, vol. 268, no. 6, pp. 530-539, 2010.
[25] Y. Shimokawa, N. Yoda, S. Kondo, Y. Yamamura, Y. Takiguchi, and K. Umehara, "Inhibitory potential of twenty five antituberculosis drugs on CYP activities in human liver microsomes," Biological \& Pharmaceutical Bulletin, vol. 38, no. 9, pp. 1425-1429, 2015.

[26] C. E. Reust, "Common adverse effects of antiretroviral therapy for HIV disease," American Family Physician, vol. 83, no. 12, pp. 1443-1451, 2011.

[27] A. Satyaraddi, T. Velpandian, S. K. Sharma et al., "Correlation of plasma anti-tuberculosis drug levels with subsequent development of hepatotoxicity," International Journal of Tuberculosis and Lung Disease, vol. 18, no. 2, pp. 188-195, 2014.

[28] R. M. López Galera, E. Ribera Pascuet, J. I. Esteban Mur, J. B. Montoro Ronsano, and J. C. Juárez Giménez, "Interaction between cat's claw and protease inhibitors atazanavir, ritonavir and saquinavir," European Journal of Clinical Pharmacology, vol. 64, no. 12, pp. 1235-1236, 2008.

[29] J. W. Budzinski, B. C. Foster, S. Vandenhoek, and J. T. Arnason, "An in vitro evaluation of human cytochrome P450 3A4 inhibition by selected commercial herbal extracts and tinctures," Phytomedicine, vol. 7, no. 4, pp. 273-282, 2000.

[30] M. Özcan and J.-C. Chaichat, "Effect of different locations on the chemical composition of essential oils of Laurel (Laurus nobilis L.) leaves growing wild in Turkey," Journal of Medicinal Food, vol. 8, no. 3, pp. 408-411, 2005.

[31] F. Conforti, M. C. Marcotullio, F. Menichini et al., "The influence of collection zone on glucosinolates, polyphenols and flavonoids contents and biological profiles of Capparis sicula ssp. sicula," Food Science and Technology International, vol. 17, no. 2, pp. 87-97, 2011.

[32] S. Murakami, W. Li, M. Matsuura, T. Satou, S. Hayashi, and K. Koike, "Composition and seasonal variation of essential oil in Alpinia zerumbet from Okinawa Island," Journal of Natural Medicines, vol. 63, no. 2, pp. 204-208, 2009.

[33] M. R. Harkey, G. L. Henderson, M. E. Gershwin, J. S. Stern, and R. M. Hackman, "Variability in commercial ginseng products: an analysis of 25 preparations," The American Journal of Clinical Nutrition, vol. 73, no. 6, pp. 1101-1106, 2001.

[34] P. N. Brown, S. J. Murch, and P. Shipley, "Phytochemical diversity of cranberry (Vaccinium macrocarpon Aiton) cultivars by anthocyanin determination and metabolomic profiling with chemometric analysis," Journal of Agricultural and Food Chemistry, vol. 60, no. 1, pp. 261-271, 2012.

[35] W. Kalt, D. A. J. Ryan, J. C. Duy, R. L. Prior, M. K. Ehlenfeldt, and S. P. Vander Kloet, "Interspecific variation in anthocyanins, phenolics, and antioxidant capacity among genotypes of highbush and lowbush blueberries (Vaccinium section Cyanococcus spp.)," Journal of Agricultural and Food Chemistry, vol. 49, no. 10, pp. 4761-4767, 2001. 


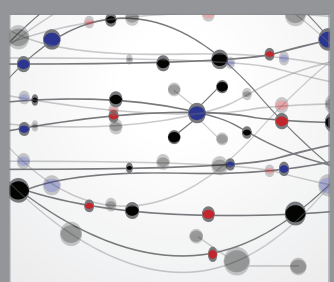

The Scientific World Journal
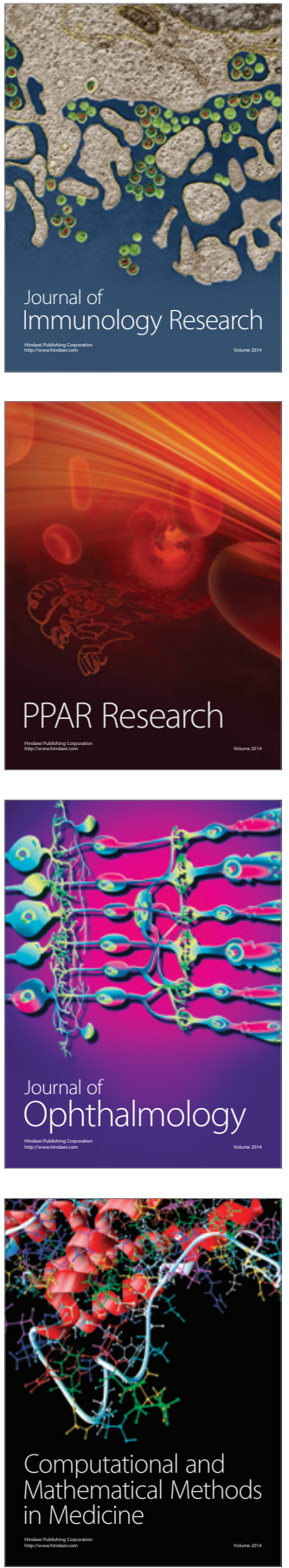

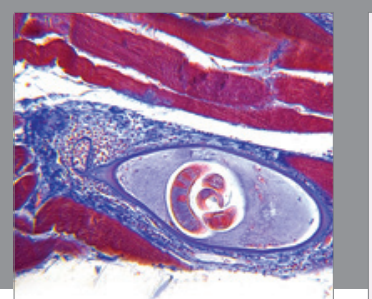

Gastroenterology Research and Practice

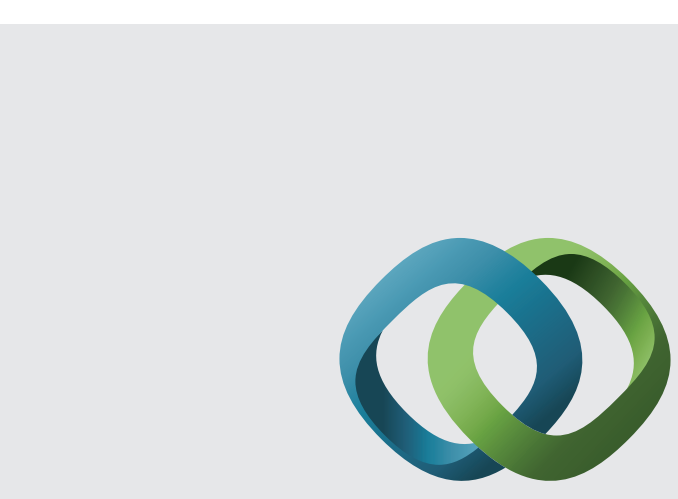

\section{Hindawi}

Submit your manuscripts at

http://www.hindawi.com
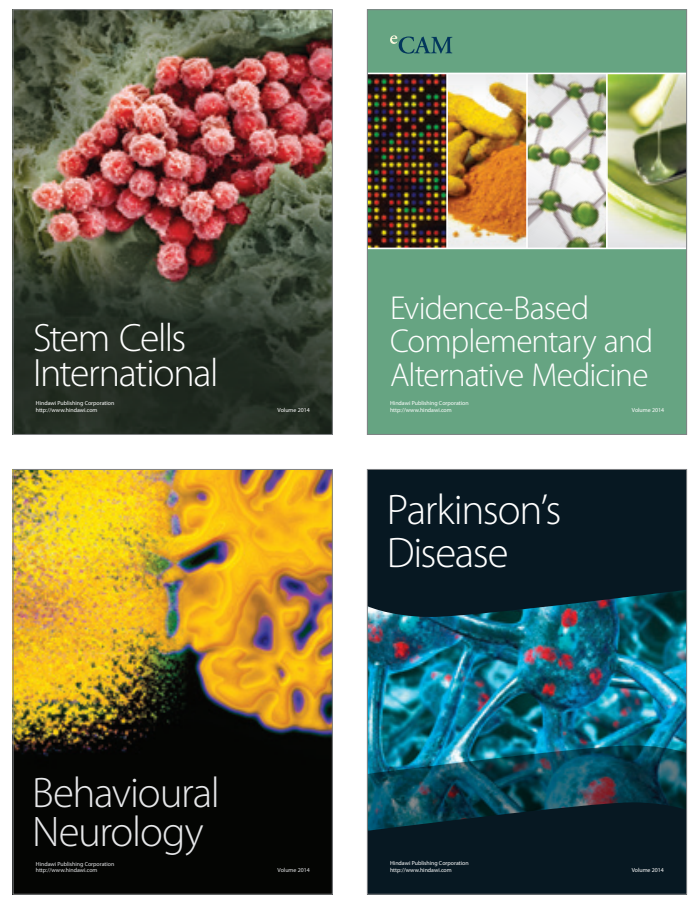
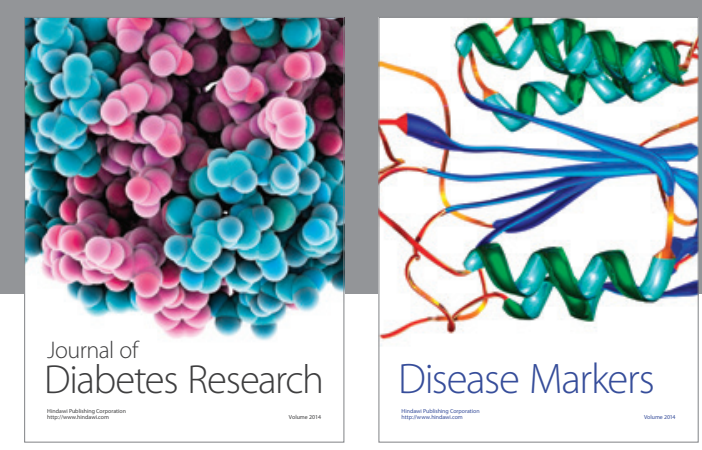

Disease Markers
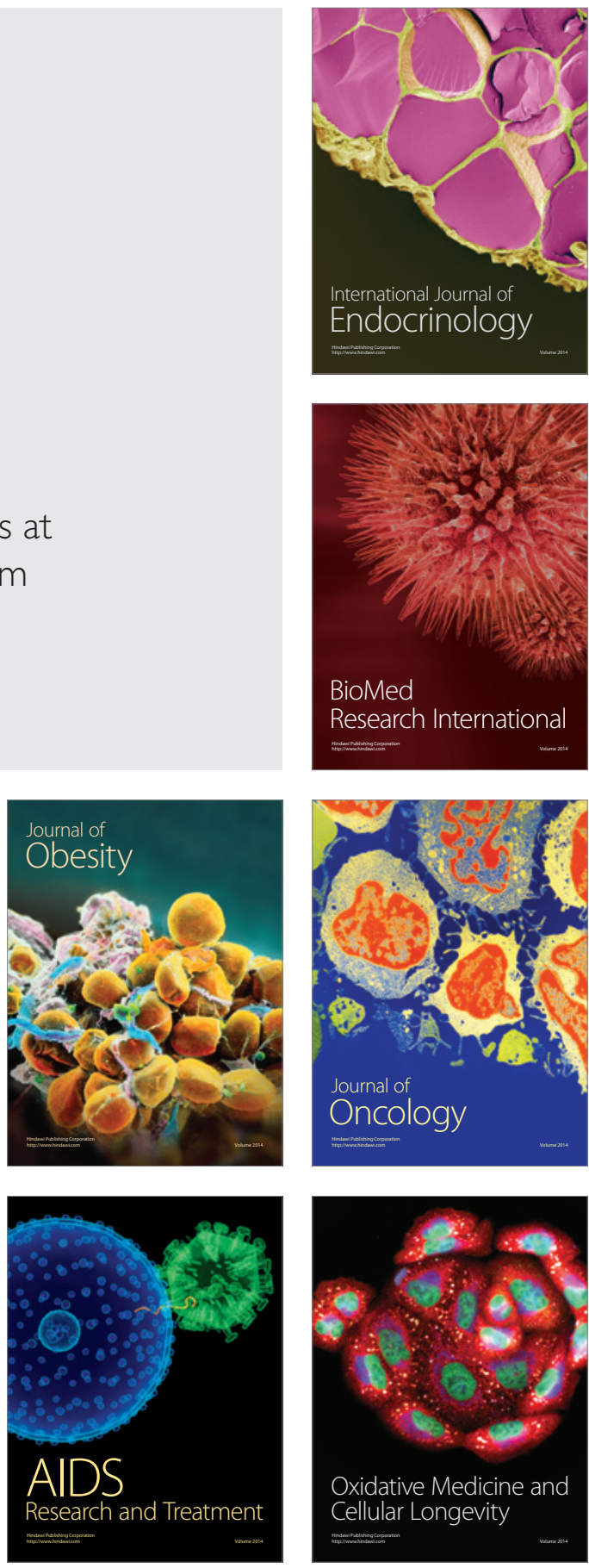